\title{
Research Paper \\ Comparison of Aggression and Sleep Habits of Athlete and Non-Athlete Children
}

\author{
Hossein Zokaei ${ }^{1}$, Fahimeh Adib Saber ${ }^{* 2}$ \\ 1. M.A. Student in Sport Management, Rasht Branch, Islamic Azad University, Rasht, Iran \\ 2. Assistant Professor, Department of Physical Education, Rasht Branch, Islamic Azad University, Rasht, Iran
}

Citation: Zokaei H, Adib Saber F. Comparison of aggression and sleep habits of athlete and non-athlete children. Quarterly Journal of Child Mental Health. 2020; 7(3): 155-166.

\section{http://dx.doi.org/10.52547/jcmh.7.3.13}

\section{A R T I C L E I N F O}

\section{Keywords:}

Aggression,

sleep habits, athlete children, non- athlete children

Received: 10 Jun 2020

Accepted: 31 Aug 2020 Available: 7 Dec 2020

\section{A B S T R A C T}

Background and Purpose: Considering the prevalence of sleep problems and the occurrence of aggression in childhood and the effect of physical activity on improving the physical and mental condition of children, the present study was conducted to compare the sleep habits and aggression of athlete and non-athlete children.

Method: The design of the present study was casual-comparative. For this aim, 120 male students studying at grades 4 to 6 of the primary school in Ardabil city in 2019-2020 were selected. Then, based on frequent attendance in sports teams, they were divided into two groups of athletes and nonathletes by purposive sampling method. Children's Sleep Habits Questionnaire (Owens, 2000) and Aggression Questionnaire for Primary School Children (Shahim, 2006) were used to gather the data. Independent t-test was used to compare the overall scores of the two groups of students and multivariate analysis of variance was utilized to compare the subscales of aggression and sleep habits of the two groups.

Results: data analysis indicated that athlete children were better than non-athlete children in both variables of aggression and sleep habits $(\mathrm{P} \leq 0.038, \mathrm{P} \leq 0.001)$. Results also showed that athlete children were significantly better than the non-athlete children in the subscales of sleep resistance $(\mathrm{P} \leq 0.003)$, sleep delay $(\mathrm{P} \leq 0.001)$, sleep duration $(\mathrm{P} \leq 0.001)$, insomnia $(\mathrm{P} \leq 0.005)$, and physical, relational, and verbal aggression $(\mathrm{P} \leq 0.001)$.

Conclusion: Therefore, it can be concluded that regular physical activity in the form of different sports can improve children's sleep patterns and reduce aggression in them.

\footnotetext{
* Corresponding author: Fahimeh Adib Saber, Assistant Professor, Department of Physical Education, Rasht Branch, Islamic Azad University, Rasht, Iran.

E-mail addresses: Adibsaber@iaurasht.ac.ir
} 


\section{مقايسه يرخاشكرى و عادتهاى خواب كود كان ورزشكار و غيرورزشكار}

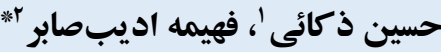

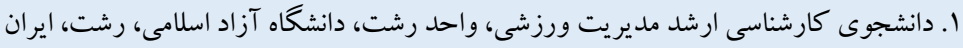

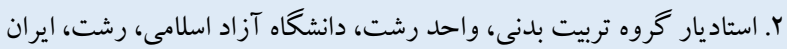

\section{جكيده}

زمينه و هدف: با توجه به شيوع مشكلات خواب و بروز يرخاشخرى در دوران كودكى و تأثير اجراى فعاليت بدنى بر بهبود وضعيت

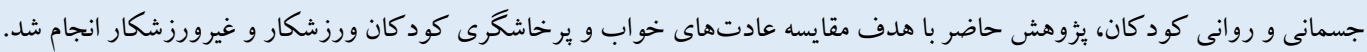

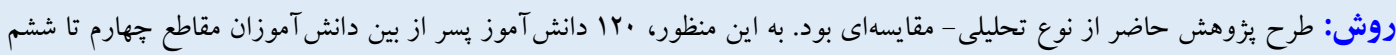

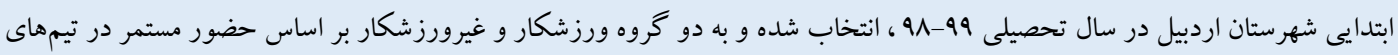

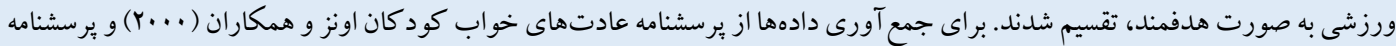

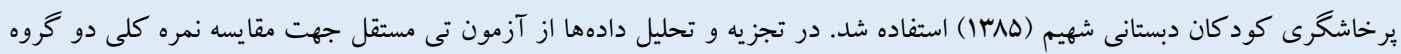

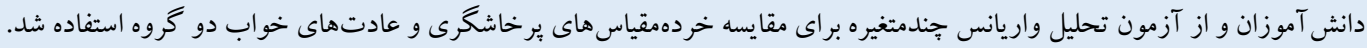

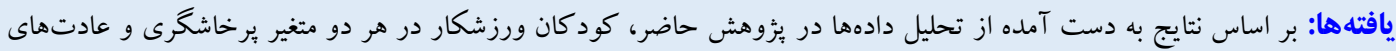

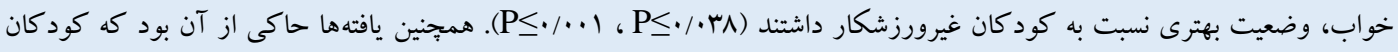

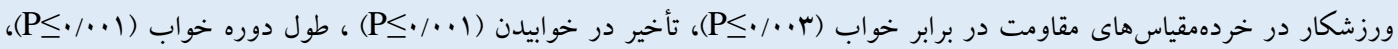

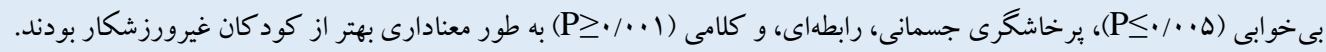

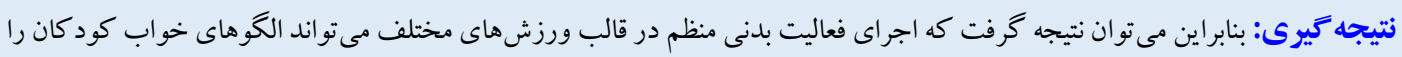
بهبود داده و موجب كاهش رفتارهاى يرخاشخر انه در آنها شود.
مشخصات مقاله

كليدوازهها: يرخاشكرى،

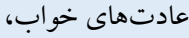

كود كان ورزشكار،

كود كان غيرورزشكار

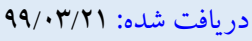

جذير فته شده: •99/19

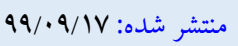

* نويسنده مسئول: فهيمه اديبصابر، استاديار گروه تربيت بدنى، واحد رشت، دانشگاه آزاد اسلامى، رشت، ايران.

رايانامه: Adibsaber@iaurasht.ac.ir

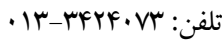


يكى از مشـكلات روانى كه تحت تأثير اختلال خواب قرار مى گيرد،

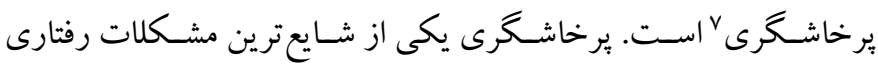

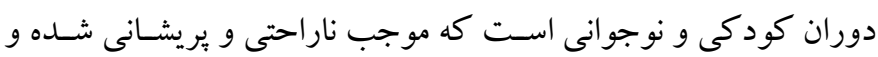

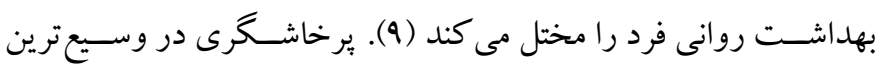

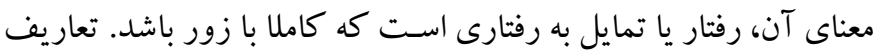

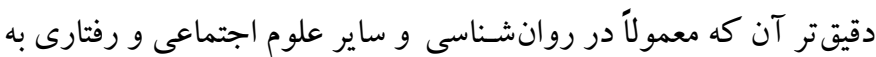

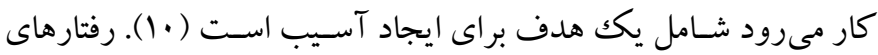

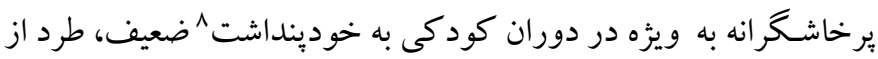

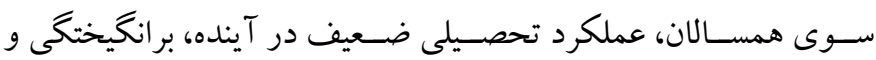

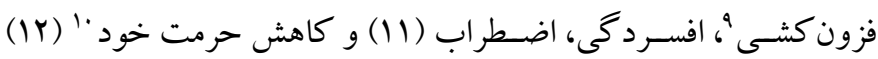
منجر مىشود.

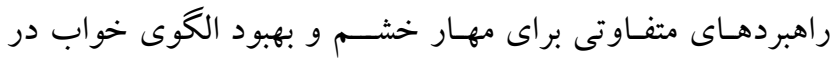

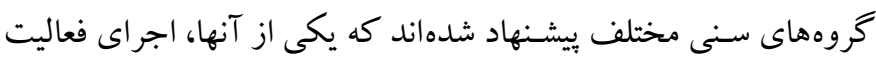
بـدنى و ورزش منظم اســت. عادت كردن به ورزش به عنوان يكك عامل

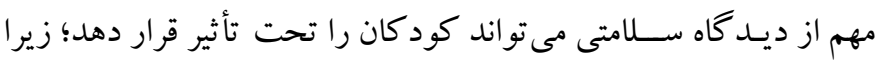
بى ترديد شـركت در برنامههاى ورزشى علاوه بر كسب قدرت، صحت و و سلامت جسمانى، آثار و نتايج روانى و اجتماعى قابل ملاحظهاى به ارمغان

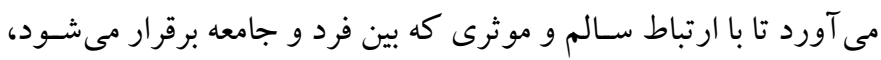

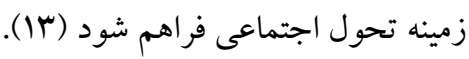
نتـايج يثزوهشهاى متعدد نشــان دادهاند افر ادى كه در فعاليت بدنى منظم شـركت مى كنند به احتمال زياد داراى مدت خو اب كافى هستند و تداوم خواب بهتر و خواب آلودگى روزانه كمترى دارند (| (1) (I). مقاله

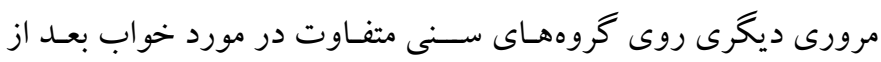
مــاخلـه ورزشــى نشــان داد كـه روزهاى همر اه با فعاليت بدنى به طور

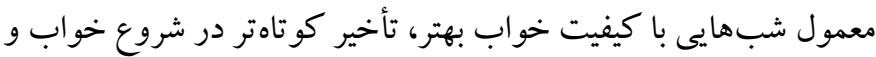

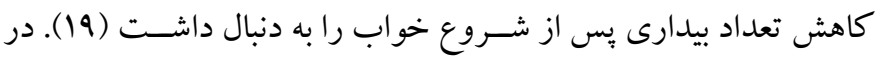

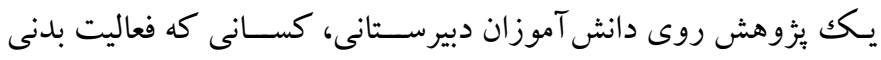

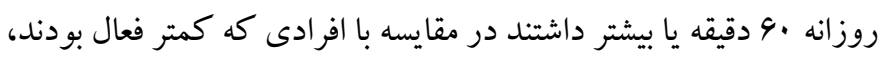

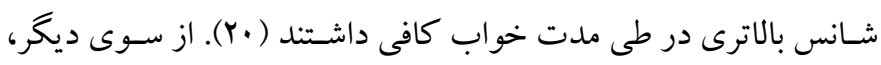

6. Attention deficit

7. Aggression

8. Self-concept

9. Hyperactivity

10. Self-esteem
مقدمه

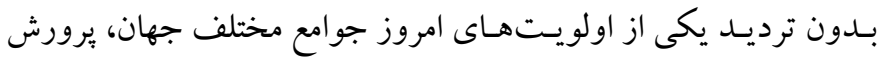

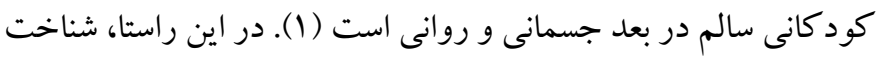

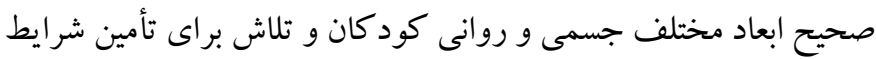

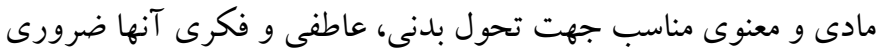
اسـت (Y). از جمله عوامل مهم موثر بر تحول جسمانى كود كان، مى توان

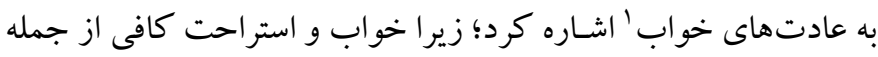
نيازهاى اوليه و اساسى است كه براى بقا و سلامتى انسان ضرورى است و و

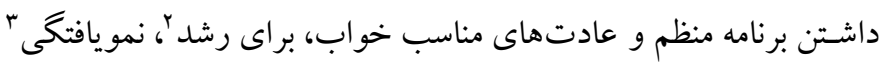

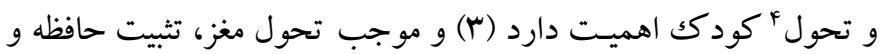

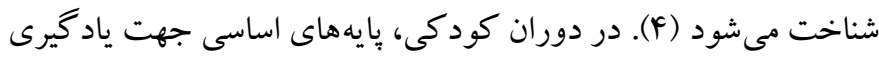

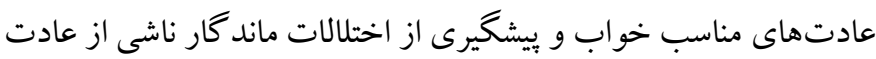

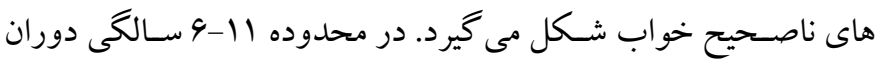

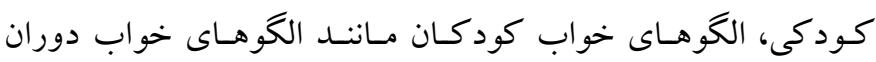

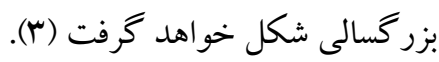
عادت هاى ناصسيح خواب، كيفيت خواب ه مطلوب را كاهش داده

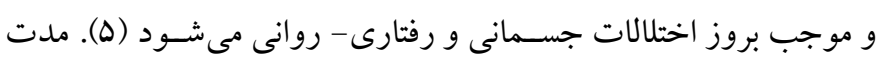

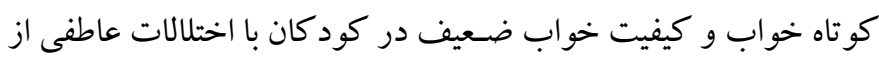

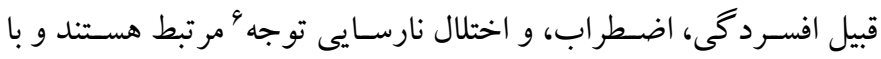

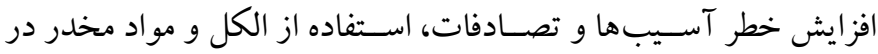

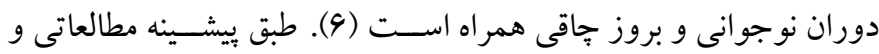

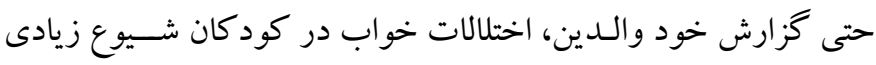

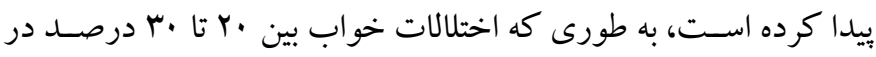

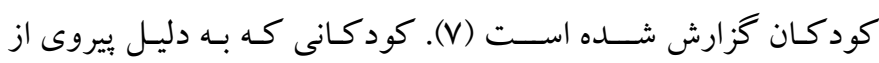
عادت هاى نامناسـب خواب و يا ابتلا به مشكلات خواب دجهار درجاتى از كم خو ابى هستـند، نسـبت به سـاير همسـالان خود عصسبانى ترند، بيشـتر از مدرسـه غيبت مى كنند، در كسـب موفقيتهاى تحصـيلى ناتوان هسـتند،

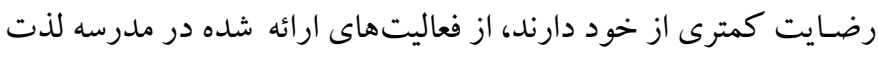
كمترى برده و حتى بيشتر بيمار مى شوند (^).

1. Sleep habits

2. Growth

3. Maturation

4. Development

5. Sleep quality 
دارد، بنـابر اين اجر ایى راهبردهـاى مؤثر جهـت بهبود عـادتهـاى خواب

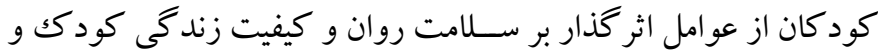

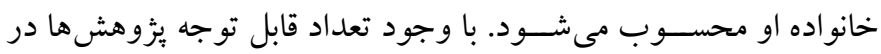

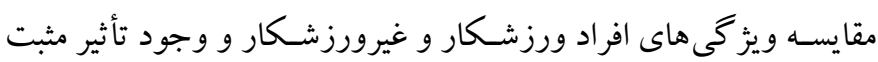
اجراى فعاليت بدنى و ورزش بر جنبه هاى مختلف تحول و سـلامت روان

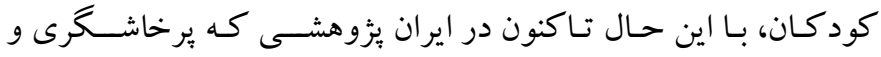
عادت هاى خواب كود كان ورزشــار و غيرورزشــار مقطع ابتدايى را

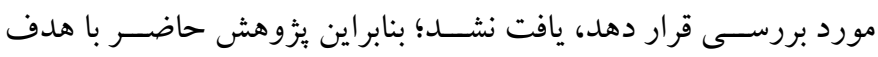

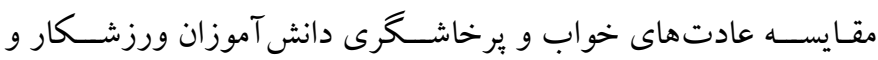
غيرورزشكار مقطع ابتدايى شهرستان اردبيل انجام شده است.

\section{روش} الف) طرح هئوهش و شر كت كنند كان: روش يزوهش حاضر توصيفى از نوع على - مقايسـاى بود. جامعه آمارى يزٔوهش حاضـر شـامل تمامى

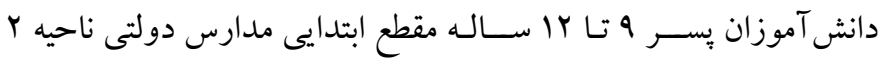

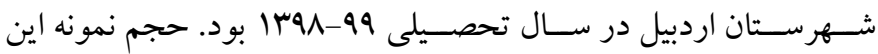

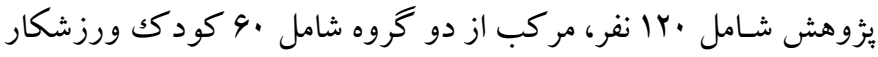

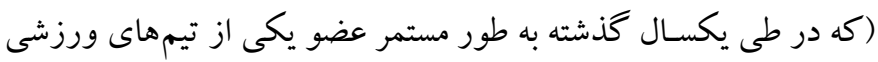
مدرسه يا باشكاهى بودند) و •4 كودكى غيرورزشكار (كه در طى يكسال

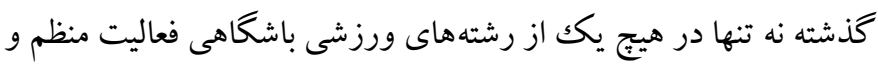

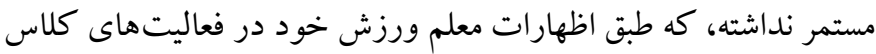
تربيت بدنى نيز حضور فعال نداشتند) بود كه به شرح زير انتخاب شدند: ابتدا كود كان ورزشكار شـناسايى و سِّ مده مدارسى كه اين كود كان در آنها مشغول به تحصيل بودند مورد شناسايى قرار گر فتند. نمونه گيرى

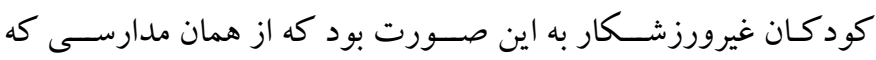

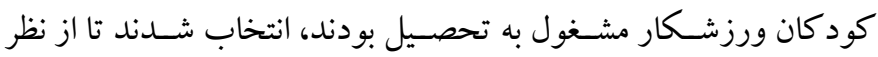

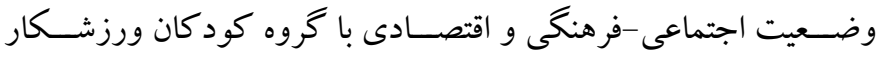

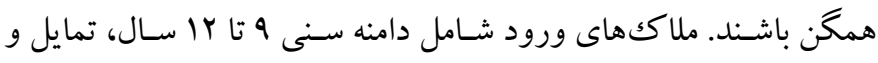

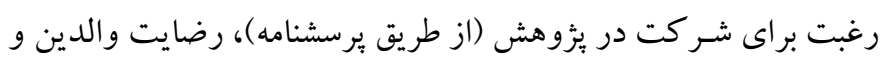

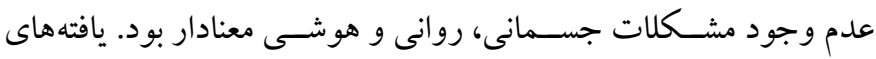

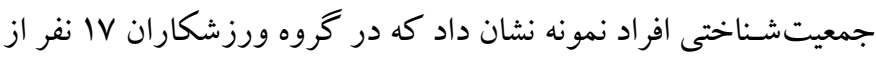

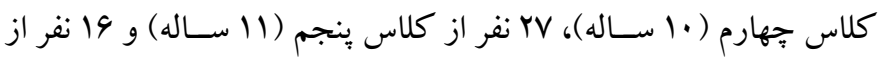

نتايج يكك مطالعه نشان داد كه ارتباط آمارى معنادارى بين زود خوابيدن،

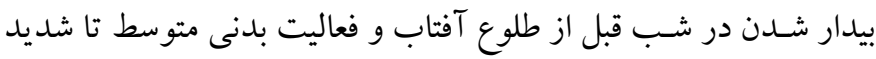

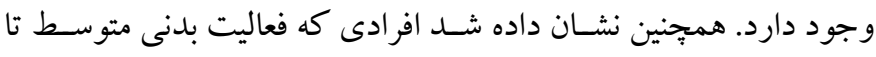
شديد انجام دادند سريع تر به خو اب مىرفتند، در طى شب دفعات كمترى بيدار مىشــند، و كيفيت خواب بهترى داشـتند (Y). در عين حال، در مطـالعهاى مرورى كـه به بررسـى ارتباط بين فعاليت بدنى و عادتهاى

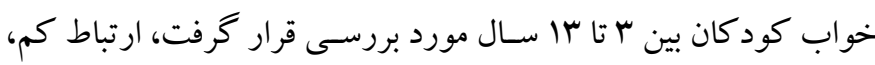

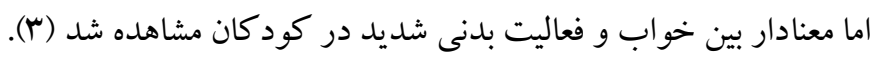

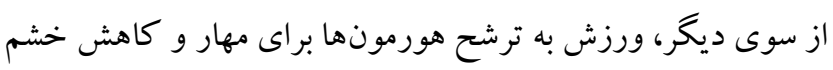

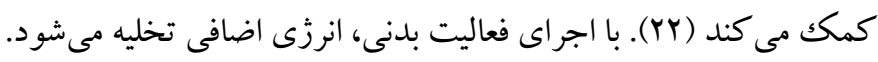
در صـورت عدم تحركى، اين انرزى اضـافى از طريق رفتار يرخاشـكرانه تخليه مىشــود و مشـكلات بســيارى براى فرد و جامعه ايجاد مى كند.

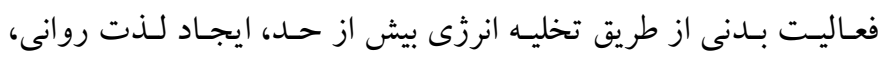

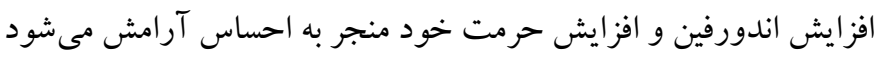

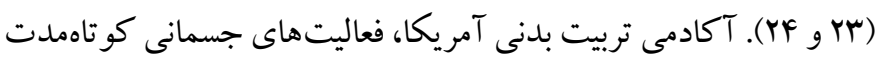

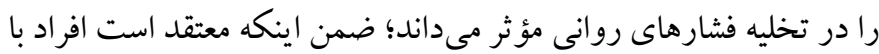

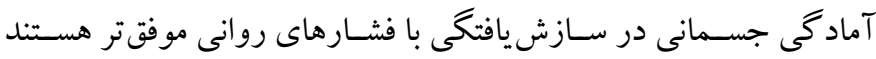

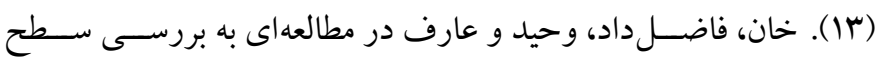

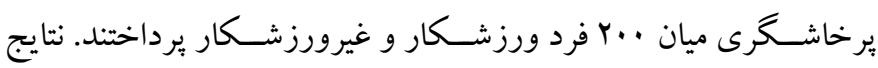

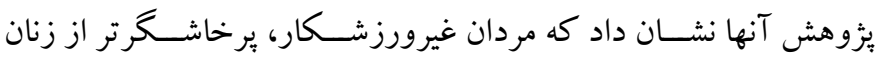
غيرورزشكار بودند. تفاوت معنى دارى بين ورزشكاران و غيرورزشكار ميردان

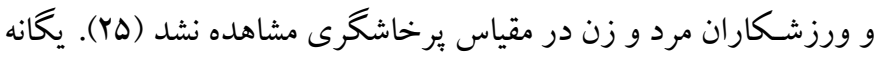

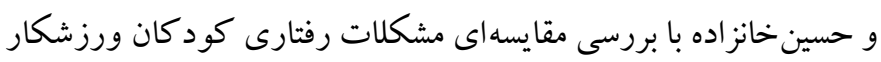

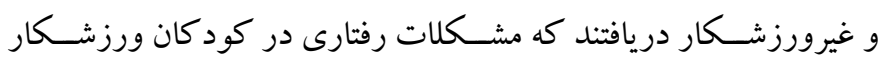
شيوع بيشترى داشت و يسران ميزان بالاترى از مشكلات رفتارى را نسبت

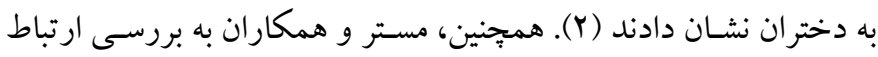
بين خواب روزانه و فعـاليـت بـدنى و رفتـارهاى بـى تحر كك در نوجوانان

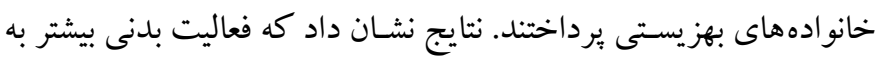

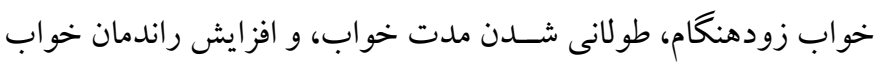

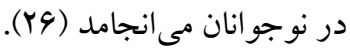

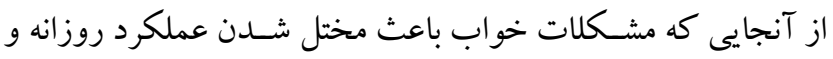

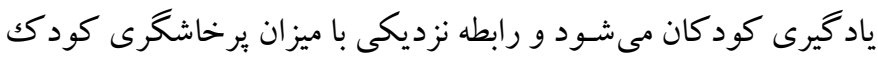


در يُوهش آنها براى كل مقياس Vه/ • و براى هر كدام از خردهمقياسها

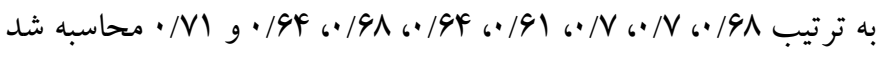

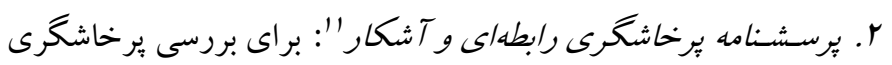

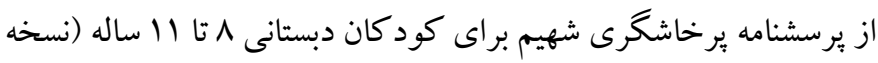

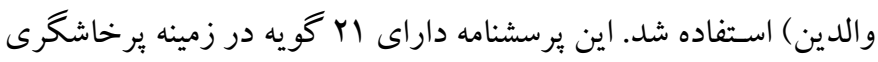

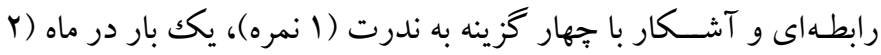

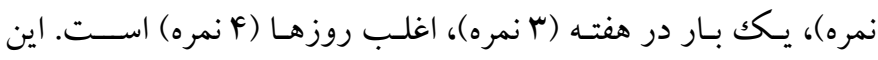

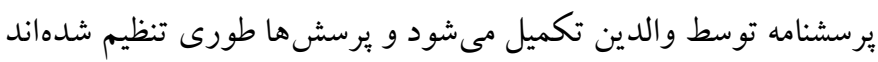

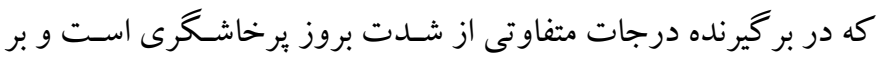

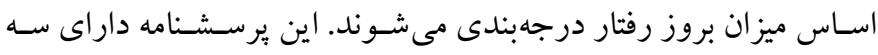

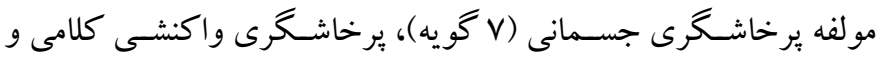

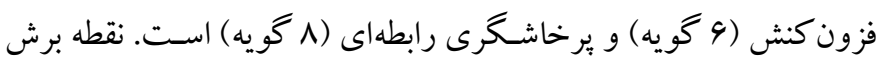

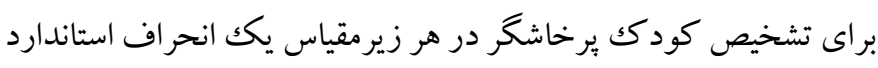

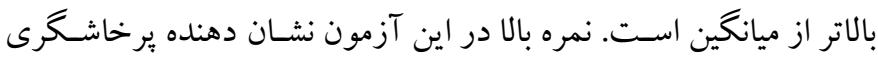

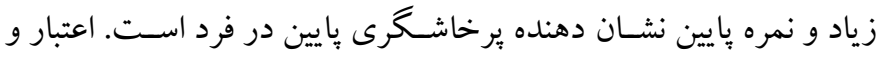

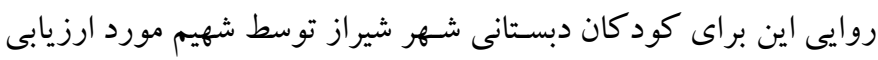

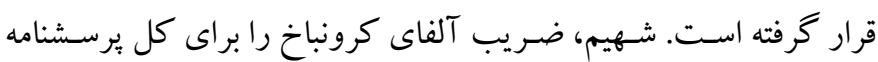

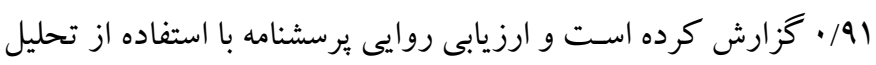

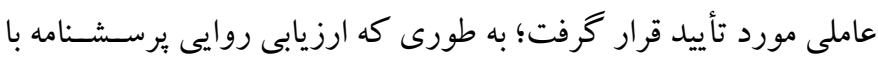

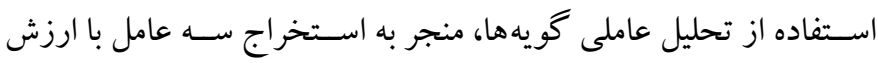

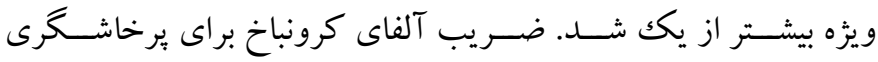

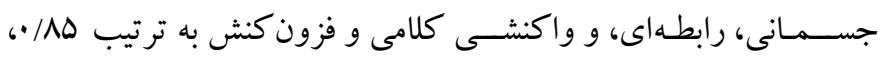

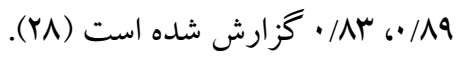
ج) روش اجرا: در ئزوهش حساضــر، بس از اخـــ مجوزهـاى لـازم از دانشـاه، ابتدا كود كان ورزشـكار در مدارس مورد نظر شــاسايى شدند.

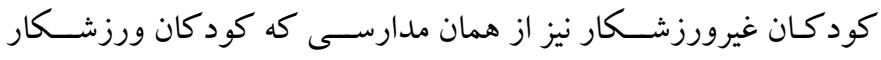

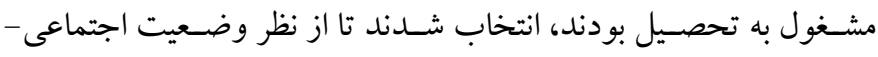

5. Sleep anxiety

6. Night wakings

7. Parasomnias

8. Sleep disordered breathing

9. Daytime sleepiness

10. Validity

11. Overt and relational aggression questionnaire
كلاس ششم (Y ساله) ابتدايى بودند. همجنين در گروه غيروززشار، M

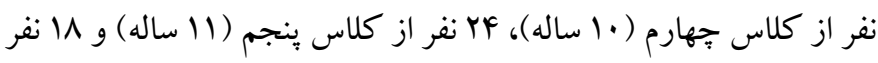
از كلاس ششم (rا ساله) بودند.

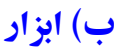
ا . برسشنامه عادت هاى خواب كودكان ': در اين بثزوهش، جهت بررسى

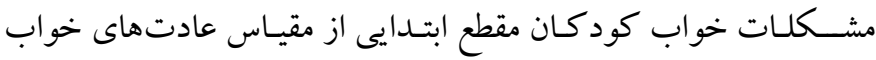

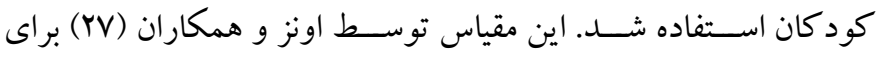

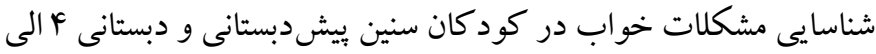
rا سال طراحى شده است و عادت هاى خواب كود كان را در هفته اخير

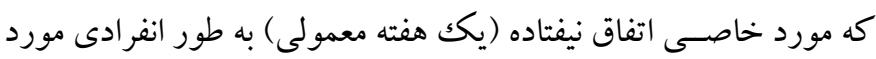

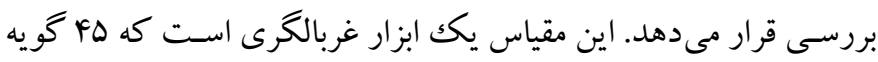

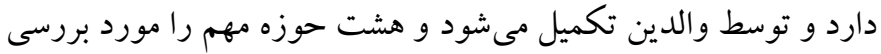
قرار مى دهد كه عبارتاند از: مقاومت در به خواب رفتن ب (شـش كويه)،

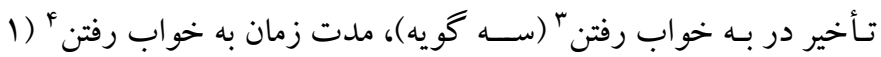

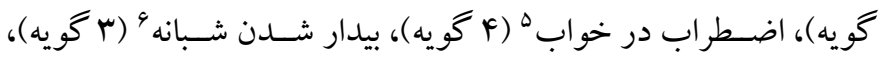

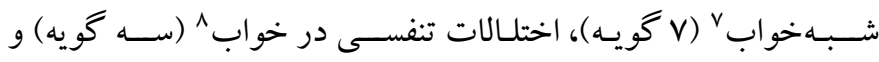

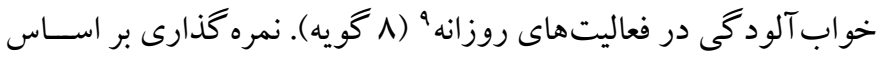

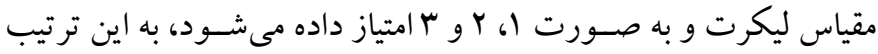

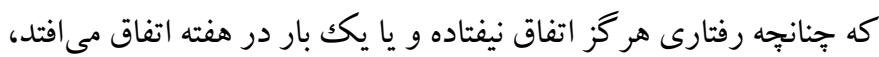

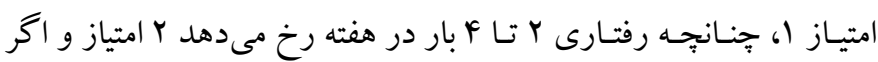
رفتارى ه بار يا بيشتر در هفته انجام شـود سه امتياز داده مى شود. بنابر اين امتياز بالاتر در اين مقياس به معناى داشـتن مشـكلات بيشتر در اين حوزه اسـت. خصـوصسيات روانسـنجى اين مقياس توسـط اونز، اسـبريتو و

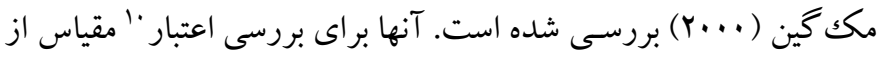

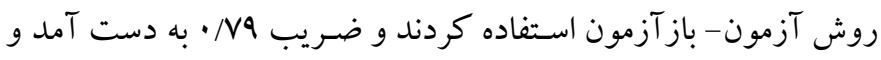

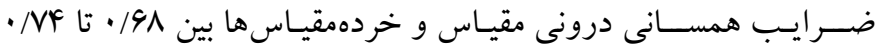

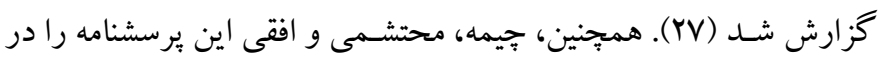
جامعه كود كان ايرانى مورد آزمون قرار دادند. ضــريب آلفاى كرونباخ

1. The Children's Sleep Habits Questionnaire (CSHQ)

2. Bedtime resistance

3. Sleep onset delay

4. Sleep duration 
از يزّوهش، حق انصـراف از يُزوهش را دارند. دادههاى جمع آورى شـده

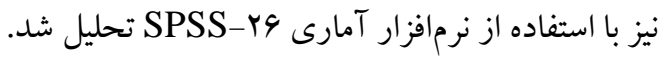

\section{يافتهها}

در جدول اشـاخص هاى توصسيفى متغيرهاى يزوهش اعم از ميانكين و

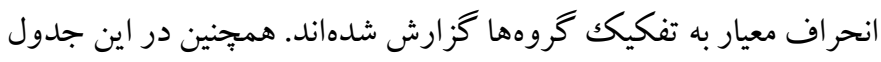

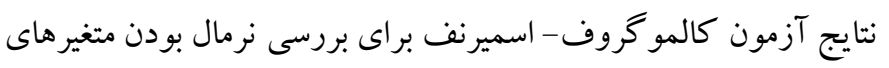

$$
\text { يزو هش محاسبه شده است. }
$$

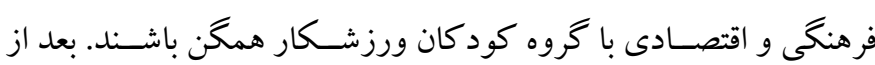

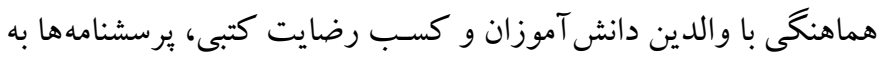

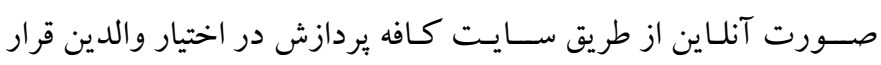

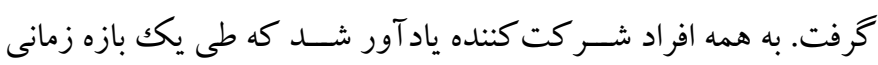

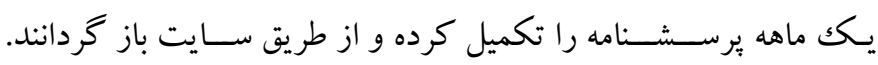

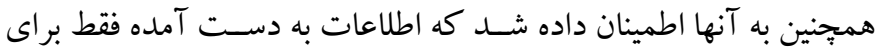
اهداف يُزوهشى استفاده مى شود و محرمانه خو اهد ماند و در هر مرحله

جدول 1: شاخصهاى توصيفى و نتايج بررسى نرمال توزيع متغيرهاى ثخوهش (تعداد: • II)

\begin{tabular}{|c|c|c|c|c|c|c|}
\hline سطح معنادارى & K-S Z Tاره & انحر اف معيار & ميانكين & خردهمقياسهاى عادت هاى خواب & شركت كنند كان & متغير \\
\hline$\cdot / r \cdot$ &.$/ .94$ & $r / \cdot V$ & $11 / 9$ & مقاومت در برابر خواب & \multirow{8}{*}{ 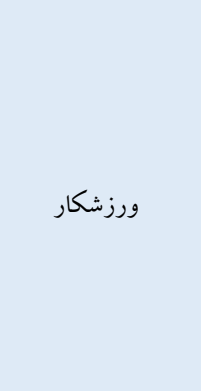 } & \multirow{22}{*}{ عادتهاى خواب } \\
\hline.$/ 81$ & .1110 & •/VTr & $1 / \Delta \Delta$ & تأخير در خوابيدن & & \\
\hline$\cdot / \Delta r$ &.$/ 11 F$ & $1 / \mathrm{V} \wedge$ & $\Delta / \Delta 1$ & طول دوره خواب & & \\
\hline$\cdot / \cdot \Delta \Lambda$ &.$/ 11$ & $r / \mu q$ & $V / \Delta 9$ & اضطراب خواب & & \\
\hline .1 .4 &.$/ 11 r$ & I/AV & $9 / 1 \pi$ & بيدار شدن از خواب & & \\
\hline.$/ \Delta r$ &.$/ 114$ & $\cdot / 4 \wedge$ & $1 Y / 9$. & شبهخواب & & \\
\hline.$/ . \Delta 9$ &.$/ 114$ & $1 / 99$ & $\Delta / A r$ & اختلال خواب & & \\
\hline$\cdot / \cdot \mathrm{vA}$ & $\cdot 1 \cdot 1$ & $r / \wedge$. & $|r / 1|$ & 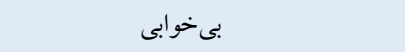 & & \\
\hline$\cdot / r \cdot$ &.$/ .91$ & $r / v q$ & $|r / r|$ & مقاومت در برابر خواب & \multirow{8}{*}{ 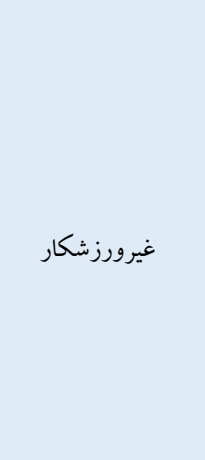 } & \\
\hline$\cdot / 0$ & .1119 & $\cdot /$ VYF & r/M & تاخير در خوابيدن & & \\
\hline.$/ . \Delta F$ &.$/ 11$ & $1 / 91$ & $9 / 9$. & طول دوره خواب & & \\
\hline$\cdot / \cdot \mathrm{vl}$ & .11 .9 & $r / 4 i$ & N/YG & اضطراب خواب & & \\
\hline.$/ .01$ & $\cdot / 11 F$ & 1/AD & $9 / 49$ & 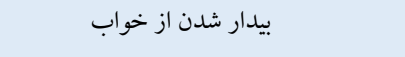 & & \\
\hline.$/ \Delta r$ &.$/ 11 F$ & $r / 99$ & $\mid r / 9 T$ & شبهخواب & & \\
\hline.$/ \cdot \Delta$ &.$/ 11 F$ & $1 / 90$ & $9 / 10$ & اختلال خواب & & \\
\hline .1 .91 &.$/ 11 r$ & F & $\mid r / 94$ & 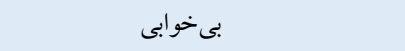 & & \\
\hline.$/ \cdot \Delta V$ &.$/ 11 r$ & $r / r q$ & $11 / \pi r$ & جسمانى & \multirow{4}{*}{ ورزشكار } & \\
\hline$\cdot / \cdot v r$ & $.11 \cdot 9$ & $r / l F$ & $11 / 49$ & 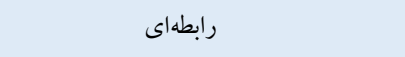 & & \\
\hline$\cdot / r \cdot$ &.$/ .94$ & r/AD & IY/A9 & 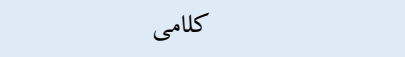 & & \\
\hline.$/ . \Delta r$ & . & $r / r)$ & $9 / 19$ & جسمانى & & \\
\hline$\cdot / \cdot \Delta 9$ &.$/ 11 r$ & $r / \Lambda \cdot$ & $\mid F / 91$ & 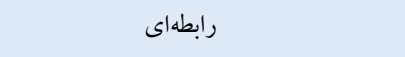 & \multirow[t]{2}{*}{ 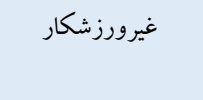 } & \\
\hline.$/ .91$ & $\cdot 11 \cdot 0$ & $r / \Delta \Lambda$ & IY/A9 & كلامى & & \\
\hline
\end{tabular}

اين يافته نشـان مىدهد كه واريانس اين متغيرها در گروهها همكن است؛ بنـابراين در جدول r نتايج آزمون تى دو نمونه مسـتقل با بيشفرض برابرى واريانسها براى نمره كل عادت هاى خواب و يرخاشـخرى در دانش آموزان ورزشكار و غيرورزشكار گزارش شده است.
با توجه به جدول ا، آماره Z آزمون كالمو گروف- اسـميرنف براى تمـامى متغيرهـاى بثزوهش در دو گرووه معنادار نيســـ؛ بنابراين مىتوان نتيجهـ گرفت كه توزيع متغيرها نرمال اســت. نتايج آزمون لوين براى

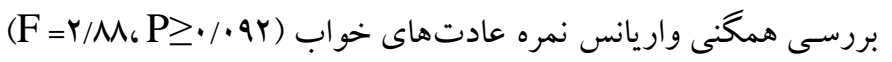
و يرخاشـرى ( 
جدول r: نتايج آزمون تى مستقل براى مقايسه نمره كل عادتهاى خواب و برخاشكرى در دو كروه دانش آموزان ورزشكار و غيرورزشكار

\begin{tabular}{|c|c|c|c|c|}
\hline سطح معنادارى & t to t & درجه آزادى & تعداد & متغير \\
\hline.$\cdots 1$ & $-\Delta / Y F$. & 111 & ir. & نمره كل عادتهاى خواب \\
\hline . & $-r / l$. & 111 & ir. & نمره كل برخاشگرى \\
\hline
\end{tabular}

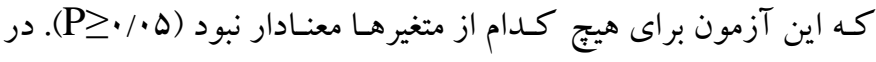

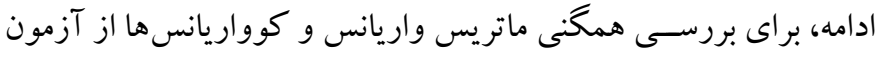

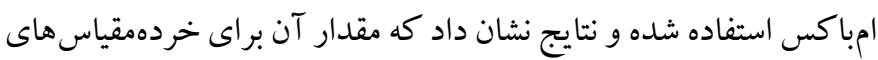
ع ع P P

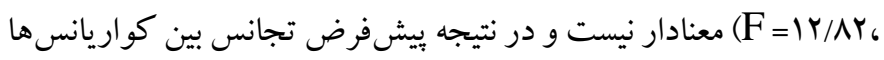

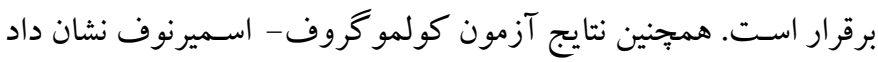

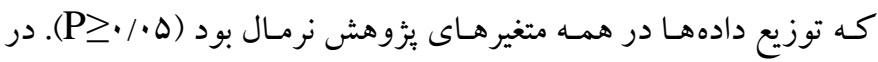

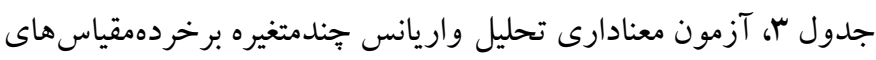
عادت هاى خواب و يرخاشگرى در دو گروه كود كان ارائه شده است.
همان گونه كه در جدول Y ملاحظه مى شود، نتايج آزمون تى مستقل

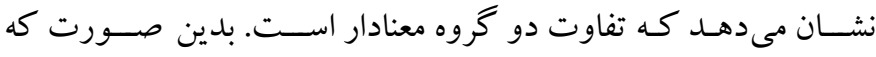

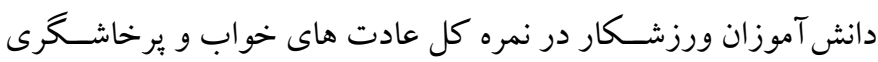

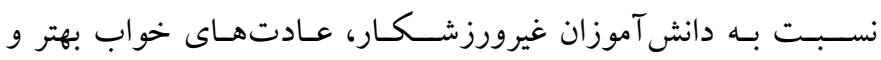

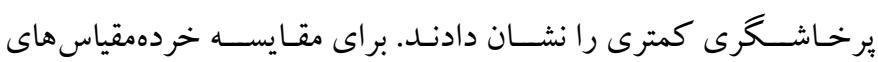

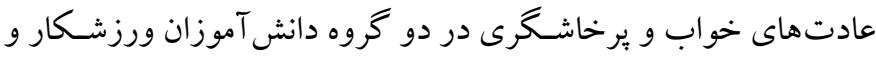

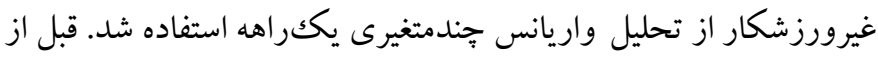

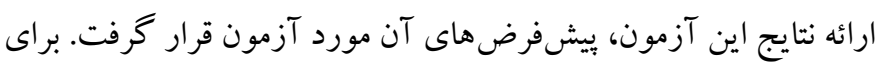

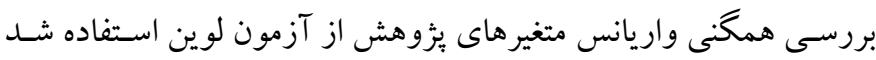

جدول بّ: نتايج آزمون معنادارى تحليلواريانس جندمتغيره بر خردهمقياسهاى عادت هاى خواب و يوخاشكرى در دو كروه دانش آموزان

\begin{tabular}{|c|c|c|c|c|c|c|c|c|}
\hline اندازه اثر & سطح معنى دارى & خطا Df & Dرضيه Df & $\mathbf{F}$ & مقدار & آماره & متغير & منبع \\
\hline$\cdot /$ rAl & $* \cdot / \cdot+1$ & 111 & $\wedge$ & $\Lambda / \Delta \Delta$ & .1919 & لامبداى ويلكز & عادتهاى خواب & \\
\hline . וז/. &.$/ . .1$ & $119 / \ldots$ & $\mu / \ldots$ & $\mid V / r \Lambda$ &.$/ 99$ & لامبداى ويلكز & يرخاشخرى & وه \\
\hline
\end{tabular}

براى بررسـى اينكـه اين تأثير بر كدام يكك از متغيرهاى وابســته معنادار اسـت، از تحليل واريانس جندمتغيره استفاده شده كه نتايج آن در جدول

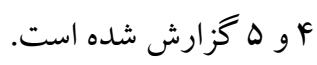

براســاس دادههـاى جـدول س، اثر كروه بر تركيـب خطى متغيرهـاى

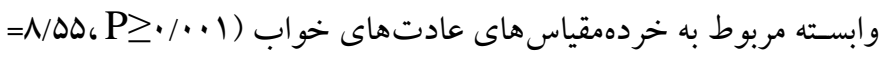

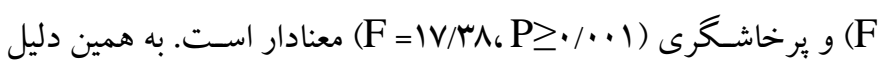

جدول ع: نتايج آزمون تحليل واريانس تكمتغيره براى مقايسه خردهمقياسهاى عادتهاى خواب در دو تروه

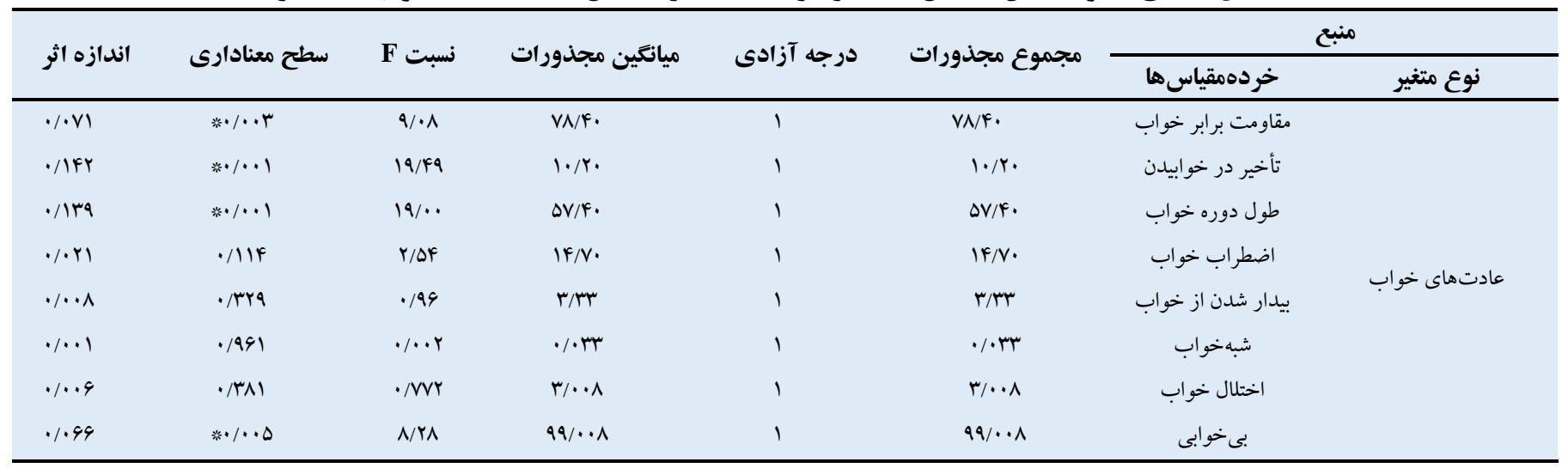


F و اختلـال خواب (F=•/VVY، P مى توان بيان داشـت كه دانش آموزان ورزشكار عادتهاى خو اب بهترى در مورد خردهمقيـاسهـاى مقـاومت در برابر خواب، تأخير در خوابيدن، طول دوره خواب و بىخوابى (T) ، نسـبت به دانش آموزان غيرورزشـكار (T)

(
همـان كونه كه در جدول \& ملاحظه مىشــود، نتايج تحليل واريانس

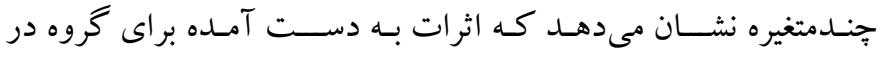

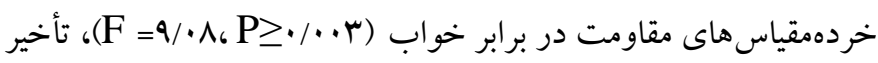
در خوابيـدن ( P

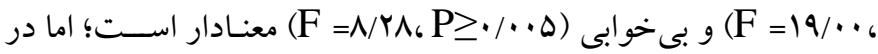
مورد خردهمقياس هاى اضـطر اب خواب (F=r/DF، P

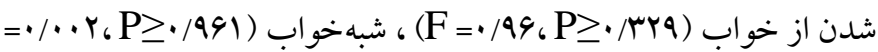

جدول 0: نتايج آزمون تحليل واريانس تكىمتغيره براى مقايسه خردهمقياسهاى يرخاشكرى در دو كروه

\begin{tabular}{|c|c|c|c|c|c|c|c|}
\hline \multirow{2}{*}{ اندازه اثر } & \multirow{2}{*}{ سطح معنادارى } & \multirow{2}{*}{ نسبت F } & \multirow{2}{*}{ ميانكين مجذورات } & \multirow{2}{*}{ درجه آزادى } & \multirow{2}{*}{ مجموع مجذورات } & \multicolumn{2}{|c|}{ منبع } \\
\hline & & & & & & خردهمقياسها & نوع متغير \\
\hline.$/ 111$ & **. $/ \cdots 1$ & $\mid F / V r$ & $1191 \cdot \pi r$ & 1 & $1191 . \mu r$ & جسمانى & \\
\hline.$/ 194$ & $* \cdot \cdot \cdot 1$ & $r \mu / \cdot V$ & $\mid V V / 94$ & 1 & $\mid V W / 94$ & رابطهاى & برخاشخرى \\
\hline$\% \Delta F$ & $* \cdot / .+1$ & 9/NG & $V N / A$. & 1 & VN/A. & كلامى & \\
\hline
\end{tabular}

خواب، و بى خو ابى معنادار اسـتـ و دانش آموزان ورزشـكار وضـعيت بهترى در خردهمقياس هاى مذكور نسبت به دانش آموزان غيرورزشـكار

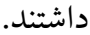

يافتهاى اين بثوهش با نتايج مطالعه مستر و همكاران همخوانى دارد. يافته هاى مطالعه مستر و همكاران نشـان داد كه فعاليت بلدنى بيشتر، منجر

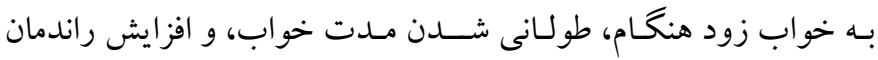

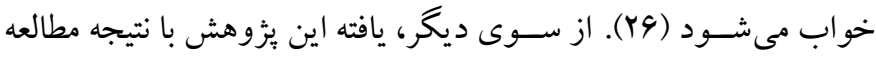

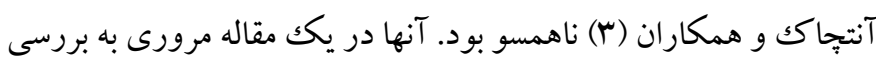
رابطه بين فعاليت بدنى و خواب كود كان س تا سا سـاله برداختند. نتايج نشــان داد كه ارتباط كمى بين فعاليت بدنى و خواب در كود كان وجود ودود

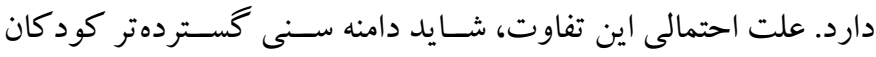

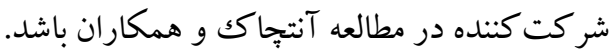

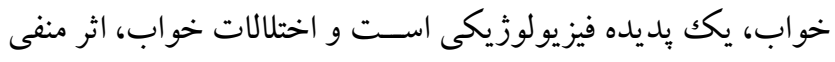

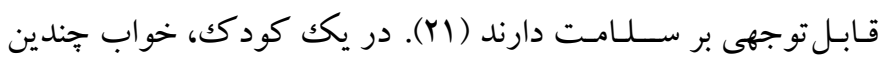
عملكرد مهم دارد؛ از جمله صسرفـهويى در انرزى، تحول مغز، تثبيت حافظه و شناخت. نظريه هاى عصب روانشناختى معتقدند كه هر كدام از بخشهـاى بـدن، حتى كوجـك ترين ســلولهـاى بدن نيز دركير فرايند

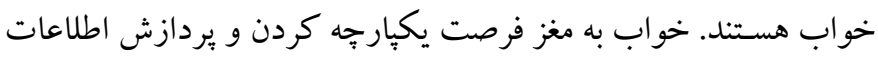

همجنين نتايج تحليل واريانس جندمتغيره نشان مىدهد كه اثرات به

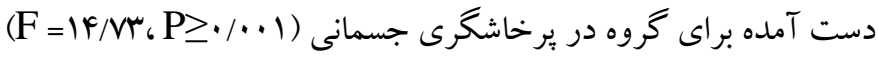

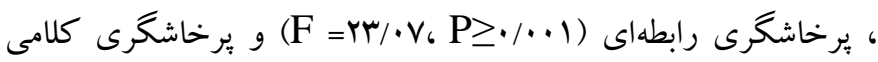

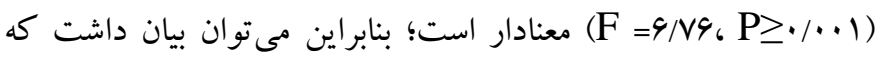
دانشآموزان ورزشكار يرخاشگرى كمترى در هر ب خردهمقياس جسمانى، رابطهاى، و كلامى ( دانش آموزان غيروزشكار (X)

\section{بحث و نتيجه تيرى}

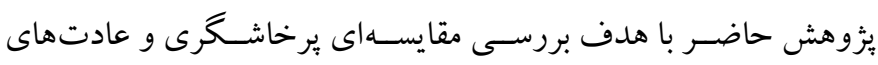
خواب كود كان ورزشكار و غيرورزشكار مقطع ابتدايى شهرستان اردبيل

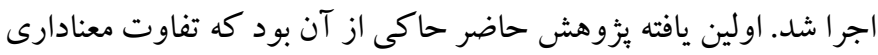

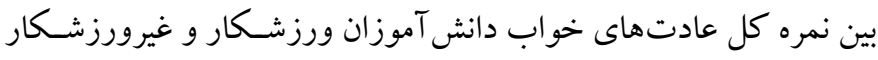

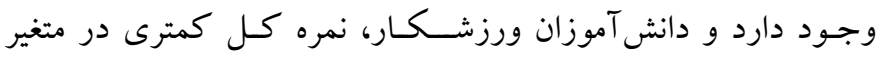

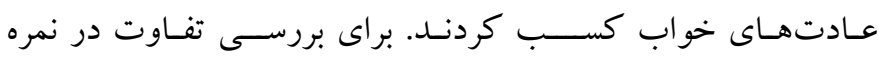

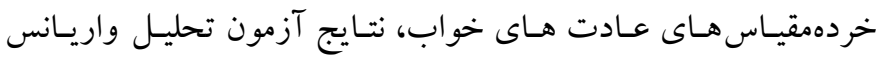

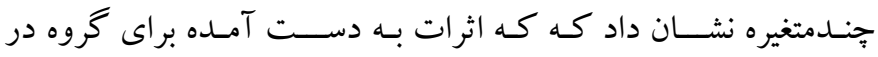
خردهمقياس هاى مقاومت در برابر خواب، تأخير در خوابيدن، طول دوره 
برخاشخرى جسمانى، رابطهاى، و كلامى نسبت به كود كان غيرورزشكار داشتند.

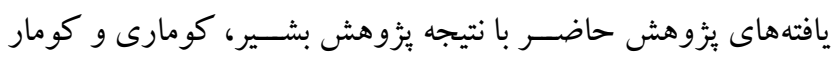

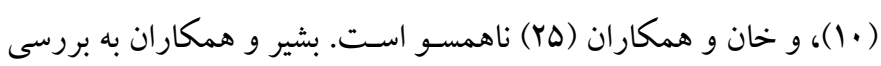

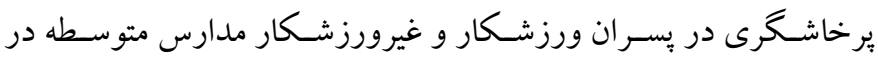

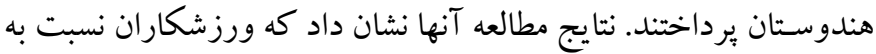

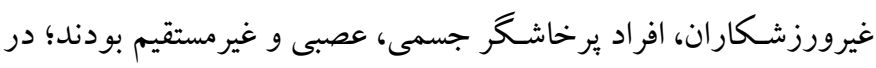

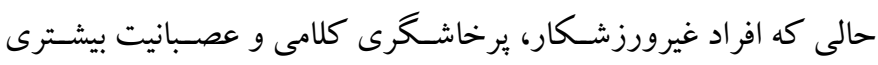

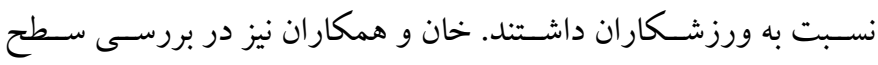

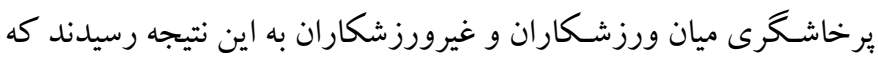
مردان غيرورزشـكار يرخاشـُ تر از زنان غيرورزشكار بودند، اما تفاوت

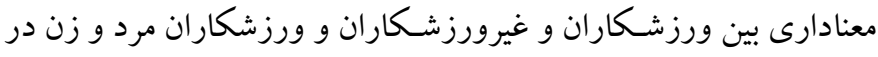

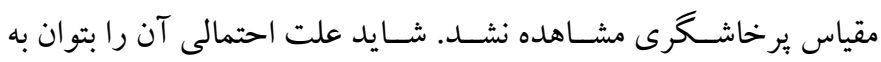
تفاوت دامنه سـنى شـر كت كنند كان در دو يثزوهش نسـبت داد. بشـير و

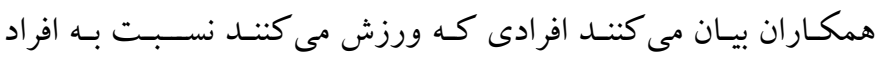

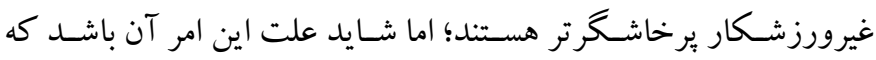
ورزش ها افر ادى را جذب مى كنند كه طبع برخاشخرى بيشترى دارند.

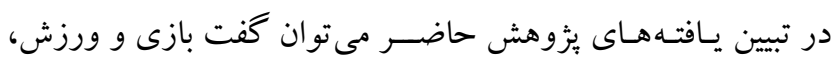

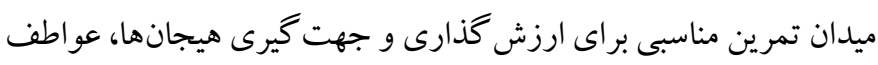

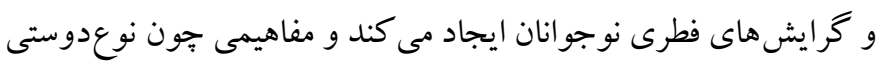

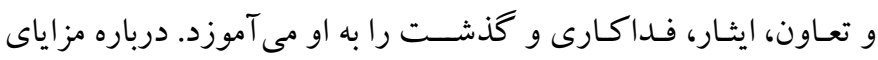
روانى تفريحات ورزشسى، فرضسيه هاى متعددى ارائه شـــ كه از آن جمله

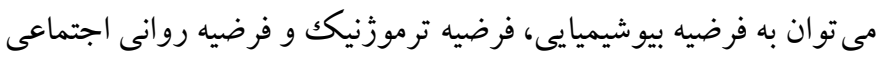

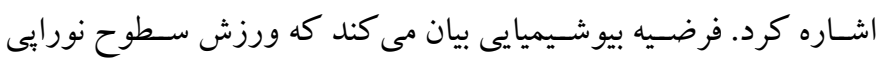

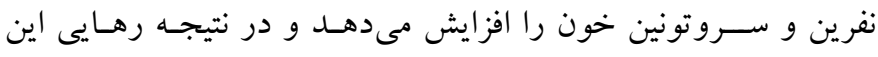

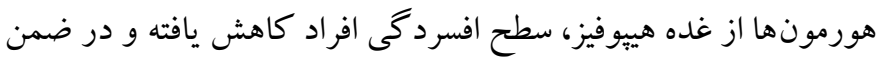

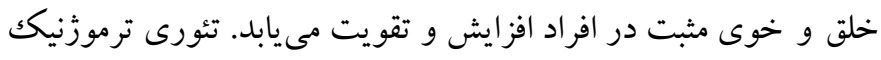

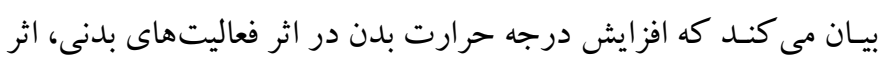

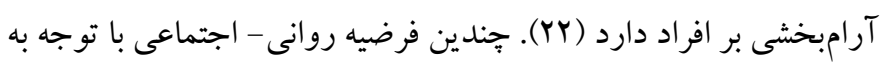

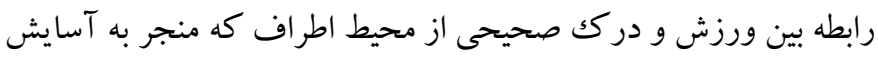
روانى مى شــود ارائه داده شــــه اســت. ورزش و فعاليت بلدنى در فرد

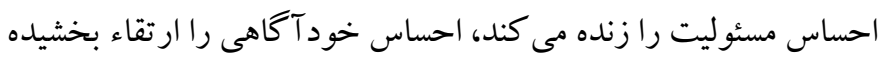

ياد گرفته شـده در طول روز را مىدهد (F). لنكك و همكاران نشان دادند

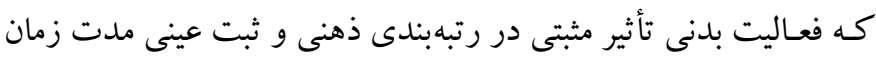

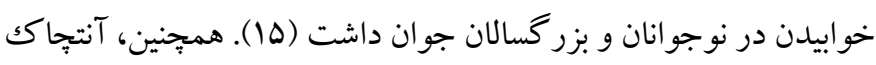

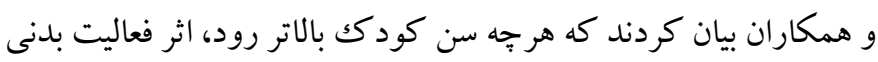
بر خواب قوى تر خو اهد شـد. يكك توضسيح احتمالى آن اسـت كه هر جهن

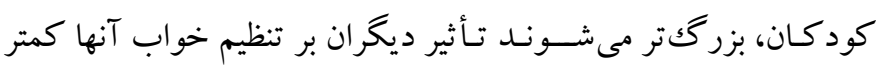

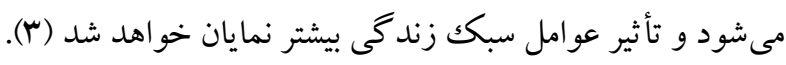

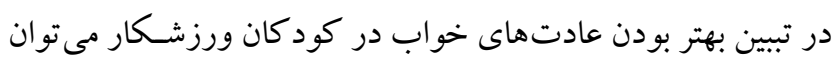
كفـت تعدادى مكانيســم نظرى بيولوزيكى وجود دارد كه بيان مى كنند

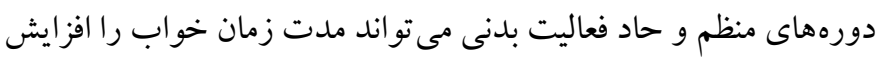

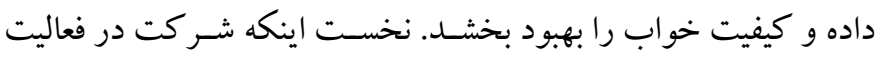

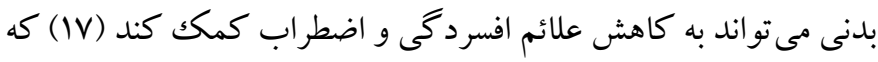
هر دو با علائم بى خو ابى ارتباط نزديكى دارند. دوم، فعاليت بدنى منجر به به إنه

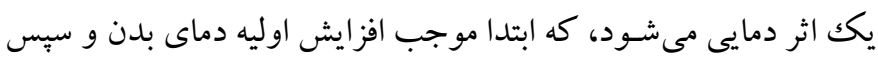

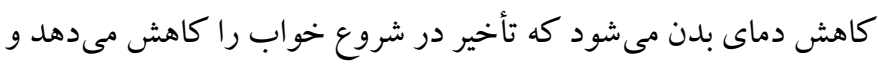

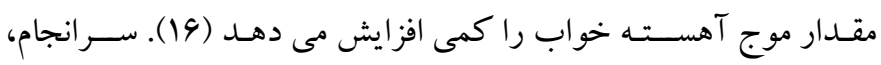

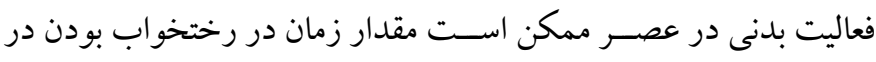

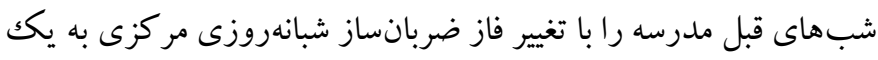

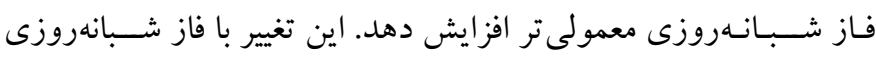
معمولى و ترجيح زمان به رختخواب رفتن بعدى مخالف است كه بخشى منى

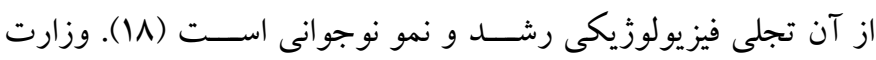

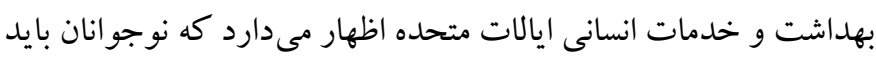

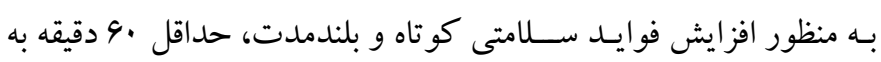

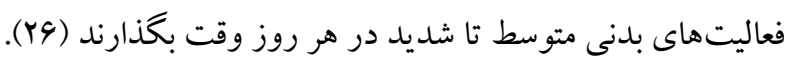

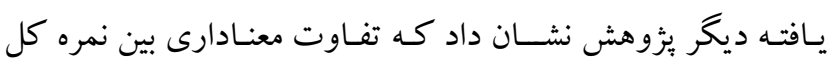

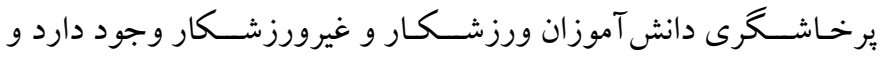

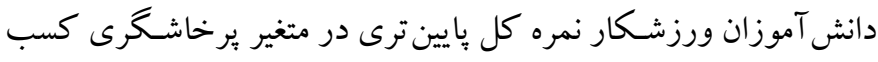

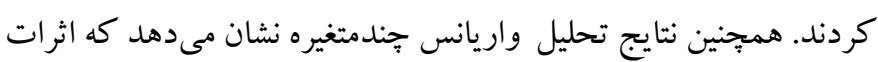

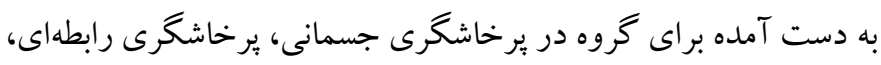

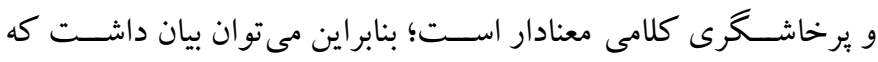

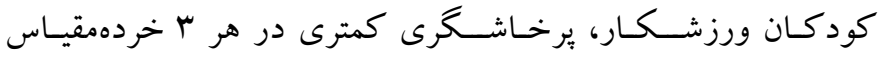


بردن مشـكلات خواب و بروز انواع برخاشــرى در جامعه كود كان كام

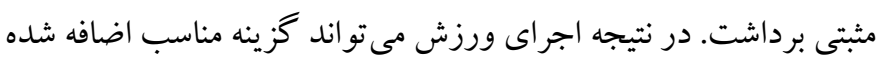
به برنامههاى آموزشى و اوقات فراغت كود كان باشد.

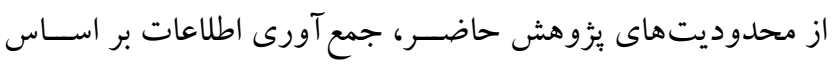

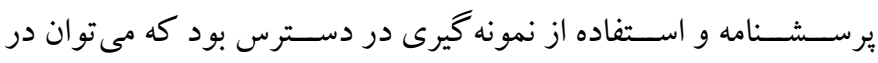
مطالعات آتى به رفع اين محدوديتهاى روش شناسى اقدام كرد. همجنين

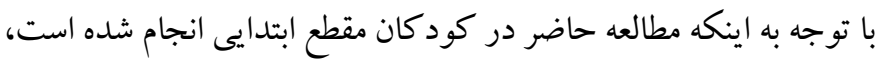

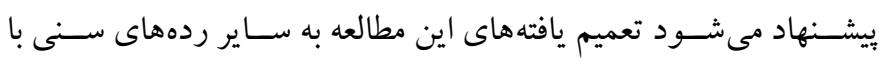

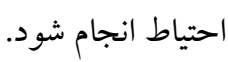

ملاحظات اخلاقى

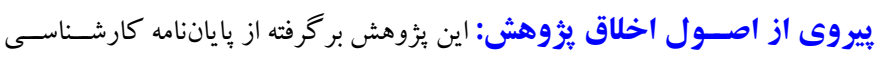

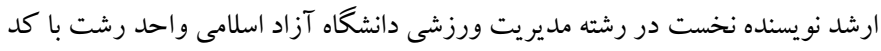

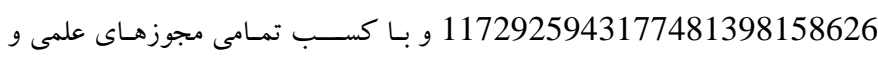

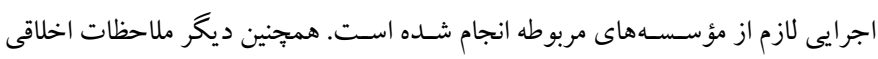

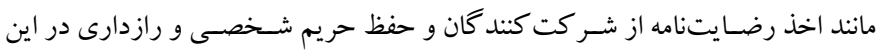

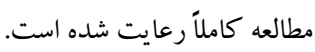
حامى مالى: اين مطالعه به طور مستقل و بدون حامى مالى انجام شده است.

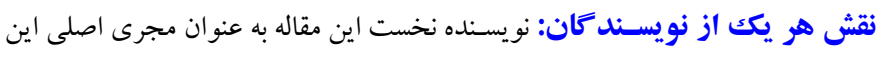

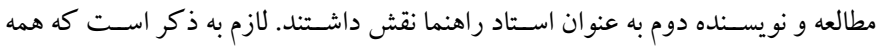
نويسند كان دستنوشته نهايى را خوانده و تأييد كردهاند.

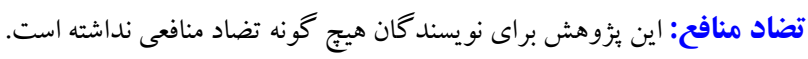

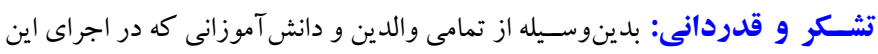

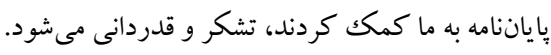

و نيز فرد را بـه لـذت بازى هاى دوران كود كى برمى گرداند. در گيرى در

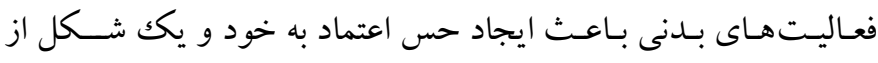

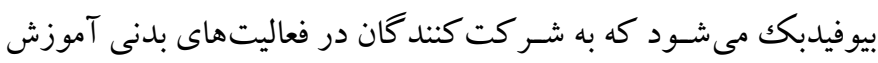

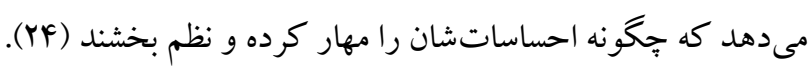

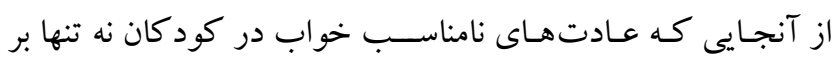

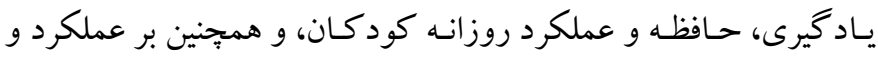

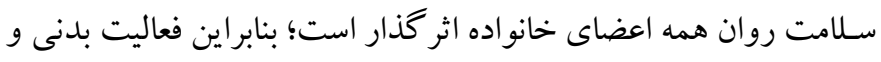
ورزش بـا فراهم كردن محيطى امن و كمهزينـه، بـاعـث تخليه هيجانى و

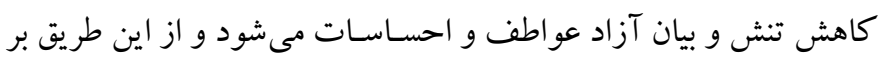

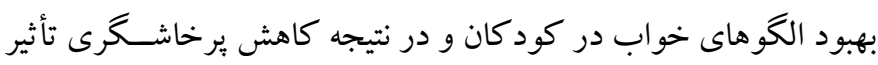

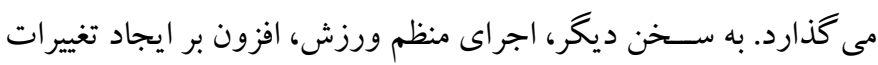

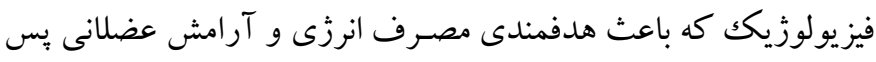
از فعاليت بدنى مى شود، آرامش جسمى و روانى را نيز به دنبال دارد.

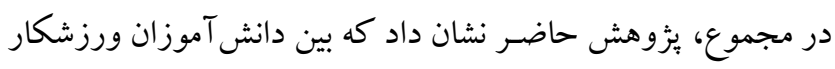

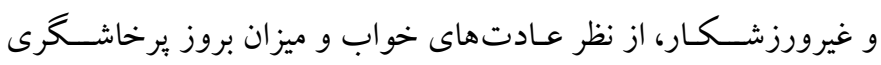

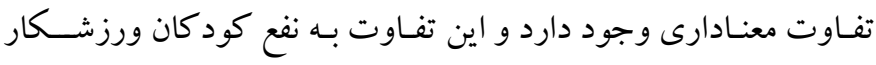

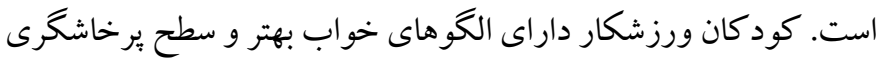

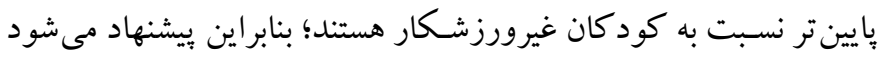

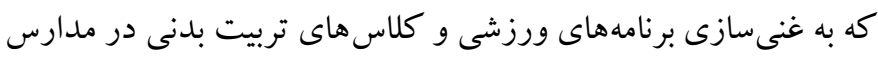

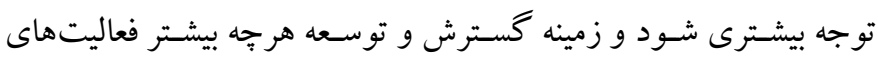
ورزشى فراهم آيد تا هرجه بيشتر در جهت بهبود سلامت روان و از بين 


\section{References}

1. Kushan M., Behnam Vashani H.R. Prevalence of some behavioral disorders and familial factors affecting primary schoolers in sabzevar. J Sabzevar Uni Med Sci, 2002, 8, 4 (22); 40 to 46. [Persian]. [Link]

2. Yeganeh T, Hosein Khanzad A A. Comparative study of behavioral problems of athlete and non-athlete children. Scientific J Kurdistan Univ Med sci. 2012; 17 (4):17-29. [Persian]. [Link]

3. Antczak D, Lonsdale C, Lee J, Hilland T, Duncan MJ, del Pozo Cruz B, Hulteen RM, Parker PD, Sanders T. Physical activity and sleep are inconsistently related in healthy children: A systematic review and metaanalysis. Sleep Medicine Reviews. 2020 1; 51:101278. [Link]

4. Kotagal S. Treatment of dyssomnias and parasomnias in childhood. Current treatment options in neurology. 2012; 14(6):630-649. [Link]

5. Ivanenko A, Barnes ME, Crabtree VM, Gozal D. Psychiatric symptoms in children with insomnia referred to a pediatric sleep medicine center. Sleep medicine. 2004; 5(3):253-259. [Link]

6. Buysse DJ. Sleep health: can we define it? Does it matter? Sleep. 2014; 37(1):9-17. [Link]

7. Chimeh N, Mohtashami T, Ofoghi H. The comparison of sleep behaviors in autistic and normal children. Journal of Exceptional Children. 2015; 15(1):17-28. [Persian]. [Link]

8. Ireland JL, Culpin V. The relationship between sleeping problems and aggression, anger, and impulsivity in a population of juvenile and young offenders. J Adolesc Health. 2006; 38(6):649-655. [Link]

9. Kamphuis J, Meerlo P, Koolhaas JM, Lancel M. Poor sleep as a potential causal factor in aggression and violence. Sleep medicine. 2012; 13(4):327-334. [Link]

10. Bashir M, Kumari S, Kumar S. Aggression and selfconcept among sports men and non-sports men: A comparative study. Internati onal Journal of Physical Education, Sports and Health. 2016; 3(6):435-439. [Link]

11. Zolrahim R, Azmoudeh M. The Effect of CognitiveBehavioral Play Therapy on Social Anxiety and Aggressive Behaviors in Primary School Children. J Child Ment Health. 2020; 6 (4) :231-240. [Persian]. [Link]

12. Ahmadi Z, Asaran M, Seyyedmoharrami F, Seyyedmoharrami I. The Relationship between Overt and Relational Aggression with Hope in Primary
School Children. J Child Ment Health. 2017; 4 (3) :143-152. [Persian]. [Link]

13. Richardson CR, Faulkner G, McDevitt J, Skrinar GS, Hutchinson DS, Piette JD. Integrating physical activity into mental health services for persons with serious mental illness. Psychiatric services. 2005; 56(3):324-331. [Link]

14. Kredlow MA, Capozzoli MC, Hearon BA, Calkins AW, Otto MW. The effects of physical activity on sleep: a meta-analytic review. J Behav Med. 2015; 38(3):427-449. [Link]

15. Lang C, Kalak N, Brand S, Holsboer-Trachsler E, Pühse U, Gerber M. The relationship between physical activity and sleep from mid adolescence to early adulthood. A systematic review of methodological approaches and meta-analysis. Sleep Med Rev. 2016; 28:32-45. [Link]

16. Buxton OM, Lee CW, L'Hermite-Balériaux M, Turek FW, Van Cauter E. Exercise elicits phase shifts and acute alterations of melatonin that vary with circadian phase. Am J Physiol Regul Integr Comp Physiol. 2003; 284(3):R714-724. [Link]

17. Carek PJ, Laibstain SE, Carek SM. Exercise for the treatment of depression and anxiety. Int J Psychiatry Med. 2011; 41(1):15-28. [Link]

18. Crowley SJ, Van Reen E, LeBourgeois MK, Acebo C, Tarokh L, Seifer R, Barker DH, Carskadon MA. A longitudinal assessment of sleep timing, circadian phase, and phase angle of entrainment across human adolescence. PloS one. 2014; 9(11): e112199. [Link]

19. Dolezal BA, Neufeld EV, Boland DM, Martin JL, Cooper CB. Interrelationship between sleep and exercise: a systematic review. Adv Prev Med. 2017. [Link]

20. Foti KE, Eaton DK, Lowry R, McKnight-Ely LR. Sufficient sleep, physical activity, and sedentary behaviors. Am J Prev Med. 2011; 41(6):596-602. [Link]

21. Badicu G. Physical activity and sleep quality in students of the faculty of physical education and sport of Brasov, Romania. Sustainability. 2018; 10(7):2410. [Link]

22. Holloway JB, Beuter A, Duda JL. Self-Efficacy and Training for Strength in Adolescent Girls 1. J Appl Soc Psychol. 1988; 18(8):699-719. [Link]

23. Malmir R, Nedaee T. The relationship between anger control and physical activity. Health. 2019; 21(4):284291. [Link]

24. Atkins MS, Stoff DM, Osborne ML, Brown K. Distinguishing instrumental and hostile aggression: 
does it make a difference? J Abnorm Child Psychol. 1993; 21(4):355-365. [Link]

25. Khan MJ, Fazaldad G, Waheed A, Arif H. Level of aggression among athletes and non-athletes. The Shield-Research Journal of Physical Education \& Sports Science. 2019; 12. [Link]

26. Master L, Nye RT, Lee S, Nahmod NG, Mariani S, Hale L, Buxton OM. Bidirectional, daily temporal associations between sleep and physical activity in adolescents. Scientific reports. 2019; 9(1):1-4. [Link]
27. Owens JA, Spirito A, McGuinn M. The children's sleep habits questionnaire (CSHQ): psychometric properties of a survey instrument for school-aged children. Sleep-New York-. 2000; 23(8):1043-1052. [Link]

28. Shahim S. Overt and relational aggression among elementary school children. Psychological Research Journal. 2006. 9. [Persian]. [Link] 